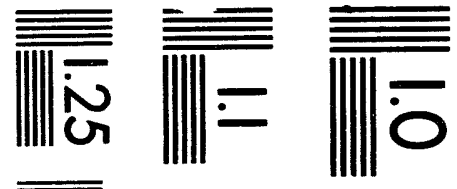

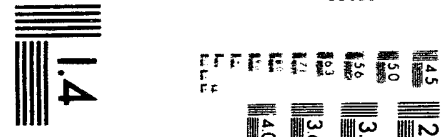

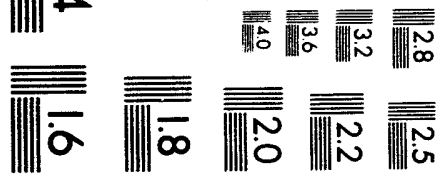



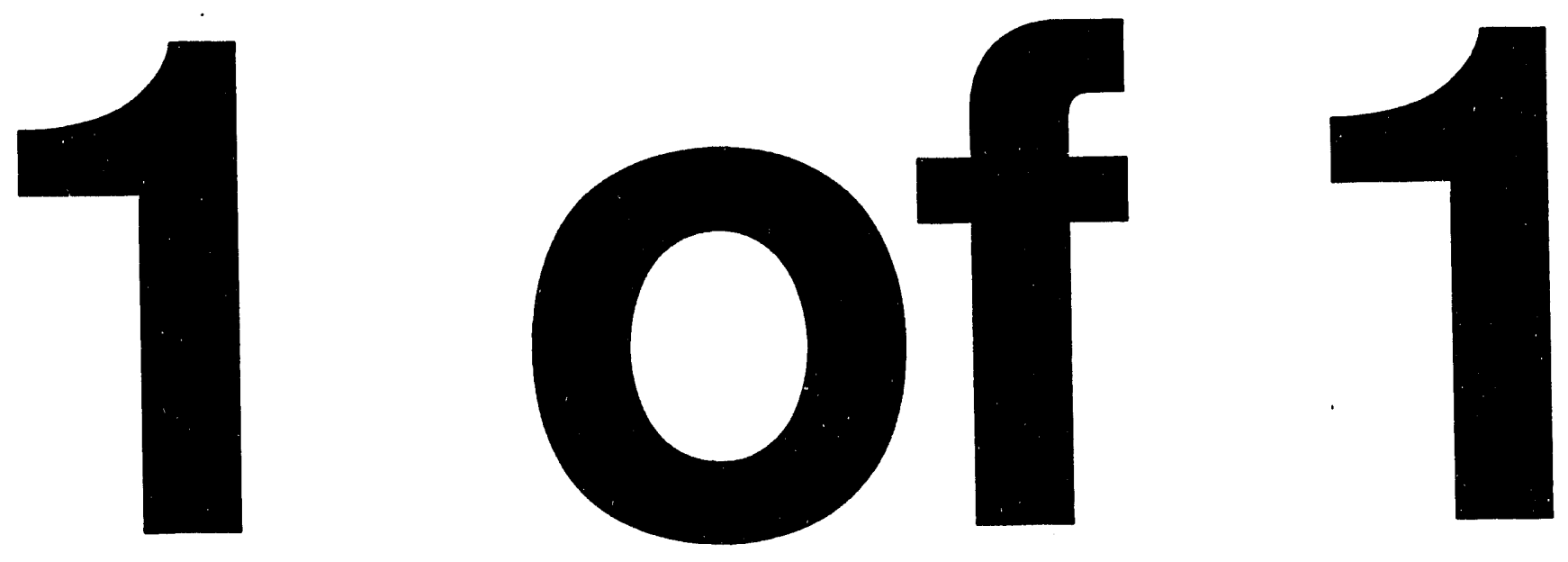


\section{IDENTIFICATION OF ITEMS AND ACTIVITIES IMPORTANT TO WASTE FORM ACCEPTANCE BY WESTINGHOUSE GOCO SITES (U)}

by

M. J. Plodinec

Westinghouse Savannah River Company

Savannah River Site

Aiken, South Carolina 29808
S. L. Marra
J. Dempster
E. H. Randklev

This paper was prepared in connection with work done under the above contract number with the U. S. Department of Energy. By acceptance of this paper, the publisher and/or recipient acknowledges the U. S. Government's right to retain a nonexclusive, royalty-free license in and to any copyright covering this paper, along with the right to reproduce and to authorize others to reproduce all or part of the copyrighted paper. 


\section{DISCLAIMER}

This report was prepared as an account of work sponsored by an agency of the United States Government. Neither the United States Government nor any agency thereof, nor any of their employees, makes any warranty, express or implied, or assumes any legal liability or responsibility for the accuracy, completeness, or usefulness of any information, apparatus, product, or process disclosed, or represents that its use would not infringe privately owned rights. Reference herein to any specific commercial product, process, or service by trade name, trademark, manufacturer, or otherwise does not necessarily constitute or imply its endorsement, recommendation, or favoring by the United States Government or any agency thereof. The views and opinions of authors expressed herein do not necessarily state or reflect those of the United States Government or any agency thereof.

This report has been reproduced directly from the best available copy.

Available to DOE and DOE contractors from the Office of Scientific and Technical Information, P. O. Box 62, Oak Ridge, TN 37831; prices available from (615) $576-8401$.

Available to the public from the National Technical Information Service, U. S. Department of Commerce, 5285 Port Royal Rd., Springfield, VA 22161 
WESTINGHOUSE SAVANNAH RIVER COMPANY

SAVANNAH RIVER TECHNOLOGY CENTER

\author{
WSRC-RP $-93-1378$ \\ Keywords: Glass \\ DWP F
}

October 12, 1993

CC: C.B. Jones, 730-B

L.M. Papouchado, 773-A

E.F. Duhn, 773-A

F.J. Leach, 773-A

P.E. Lowe, 773-42A

M.K. Carlson, 704-S

W.T. Goldston, 704-S

S.L. Marra, 704-35S

A.A. Ramsey, 704-35s

J.F. Sproull, 704-S

Glass Tech. Group

E.T. Weber, WHC

T. Kocialski, WVNS

TIM, 703-43A (4)

TO: $\quad$ E.W. Holtzscheiter, 773-A

FROM: M.J. Plodinec, 7735A $\quad$ S.L. Marra, 704-35S

J. Dempster, WVDP

E.H. Randklev, HWVP

IDENTIEICATION OF ITHMS AND ACTIVITIFS IMPORTANT TO WASTE EORM ACCFPTANCF BY MFSTINGHOUSE GOCO SITES (U)

\title{
INTRODUCTION AND SUMNARY
}

The Department of Energy has established specifications (Waste Acceptance Product Specifications for Vitrified High-Level Waste Forms, or WAPS) for canistered waste forms produced at Hanford, Savannah River, and West Valley. ${ }^{1}$ Compliance with these specifications requires that each waste form producer identify the items and activities which must be controlled to ensure compliance.

As part of quality assurance oversight activities, reviewers have 
tried to compare the methodologies used by the waste form producers to identify items and activities important to waste form acceptance. Due to the lack of a documented comparison of the methods used by each producer, confusion has resulted over whether the methods being used are consistent. This confusion has been exacerbated by different systems of nomenclature used by each producer, and the different stages of development of each project.

The waste form producers have met three times in the last two years, most recently on June 28, 1993, to exchange information on each producer's program. These meetings have been sponsored by the Westinghouse GoCo HLW Vitrification Committee. This document is the result of this most recent exchange. It fills the need for a documented comparison of the methodologies used to identify items and activities important to waste form acceptance. In this document, the methodology being used by each waste form producer is summarized, and the degree of consistency among the waste form producers is determined.

\section{CONCIUSIONS}

The major conclusions, drawn by the GoCo committee are:

- The methods being used by the waste form producers are mutually consistent.

- The lists of items and activities are necessarily somewhat different, reflecting the different processes and stages of development of each site, and differences in compliance strategies. Thus, the lists of items and activities cannot be the same - consistency in approach is all that can be expected.

- There will be significant benefits to each site and to our DOE customers if interactions on this topic continue

\section{BACKGROUND}

Vitrified waste forms produced by the Defense Waste Processing Facility (DWPF), Hanford Waste Vitrification Plant (HWVP), and West Valley Demonstration Project (WVDP) must comply with the WAPS.1 One of the specifications in the WAPS (4.0) requires that the waste form producer establish a quality assurance program which satisfies repository quality assurance requirements. This in turn requires that each waste form producer identify the items and activities which must be controlled to ensure compliance with the WAPS. These sets of items and activities define the scope of the quality assurance programs which must satisfy repository requirements.

Over the course of the last two years, reviews of the waste form producers' quality assurance programs (audits, surveillances, evaluations) have identified potential inconsistencies in the methods used by the producers. These reviews have necessarily 
been fragmentary, however, so that it has been difficult to determine whether there truly were inconsistencies. In addition, there exist several other significant barriers to making a valid comparison.

One of the most important barriers is the lack of a common nomenclature. DWPF documents refer to items and activities important to waste acceptance. HWVP refers to Waste Acceptance Process accivities (WAPA). WVDP refers to HLW items and activities. In this document, these will be referred to as items and activities important to waste form acceptance.

The waste form producers are deploying somewhat different processes. This also serves as a barrier to comparing their approaches. For example, west valley is using ion exchange resins to remove cesium from soluble waste (Hanford probably will as well); Savannah River will use sodium tetraphenylborate. The DWPF will add its glassforming chemicals in the form of glass frit; WVDP will use raw chemicals. HWVP and DWPF will use frit blasting to decontaminate canisters; WVDP will probably use a chemical cleaning method.

Failure to recognize that the waste form producers are in different stages of development has also served as a barrier to making a valid comparison. The DWPF and WVDP are relatively mature projects; much of their development, design, and construction was completed prior to the imposition of repository quality assurance requirements. Both of these projects have a large number of operating procedures, which can affect the ability of the canistered waste form to satisfy the WAPS. Both of these projects are currently qualifying their waste forms. Thus, both have tended to focus more on the activities important to waste form acceptance rather than to design and procurement of equipment.

Conversely, HWVP is a relatively young project, still in the design phase. Its strategy for satisfying the WAPS is still in transition. Thus, HWVP is currently more focused on pieces of equipment (items), rather than activities.

After two earlier meetings on this subject (11/91 and 8/92), the Westinghouse GOCO HLW Vitrification Committee sponsored a meeting (held 6/28/93 in Richland WA) to try to reach a common basis for understanding. The meeting resulted in a plan to draft a position paper which would summarize the methodologies used by each producer, and to compare them. This document results from that plan. Representatives from each waste form producer (S. L. Marra from DWPE, J. Dempster from WVDP, and R. E. Johnson/E. H. Randklev from HWVP) submitted sections which described their respective approach to identifying items and activities important to waste form acceptance. These were compiled and edited by $M$. J. Plodinec (supporting DWPF). Each of the producer organizations reviewed and accepted the document before it was issued; thus, it represents a consensus position. 


\section{METHODOTOGY USED BY MASTE FORM PRODUCERS}

The methodologies used by the producers are detailed in Attachments 1 - 3. In general, each of the sites has followed a common methodology, focused on a failure mode analysis. However, as noted below, there are some minor differences in implementation.

Establishment of Bases. Each of the producers are using information about their process and their compliance strategies as the basis for determining whether an item or activity is important to waste form acceptance. The Waste Form Compliance Plan (WCP) is the primary basis for this determination for the DWPF. The DWPF WCP reflects both the DWPF process and the strategies for compliance with the WAPS. For WVDP, the determination was made on the basis of a process flowchart detailing the entire production process. The importance of each item or activity was individually determined based on the West Valley compliance strategies. For HWVP, preliminary compliance strategy and WAPA reporting documents (e.g., WAPA rationale document, and WAPA analysis reports), are serving as the bases for making this determination.

Application. Each of the producers are using a form of failure mode analysis to determine whether an item or activity is important to waste form acceptance.

For the DWPF (Attachment 1), teams of technical personnel analyzed each DWPF system, to determine whether failure of the item or activity could result in a non-conforming waste form, or loss of data required for either the Production Records, or the storage and Shipping Records. For each system, the team consisted of technical personnel cognizant of the specific system, and members cognizant of the WAPS. Iskikawa cause-effect diagrams were used to document the teams' results. These were then collected, and the results summarized in an internal report. These then became the initial list of items and activities.

For the WVDP (Attachment 3), a single team went through the entire process. The team included processing personnel, and personnel cognizant of the WAPS. The criteria used were essentially the same as used by the DWPF, with the addition of consideration of time required to remediate a failure. A determination was made for each item and activity, and individualiy documented.

For the HWVP (Attachment 2), the same type of failure mode analysis is being followed. However, since the HWVP is still in the design and $R / D$ stage, this has only been applied to design and $R / D$ activities as yet. Initial determinations were made on single systems and then single components within the system. Interaction with other systems or use of administrative controls were not considered. Thus, the initial lists of items and activities were very conservative (i.e., broadly inclusive). As the design, and 
research and development activities, have matured, the list of items and activities has been periodically re-examined, to integrate progress made. This has allowed the elimination of some items whose function in terms of compliance with the WAPS was duplicated by other items. This consolidation will continue throughout the design and $R / D$ stages.

Maintenance and Modification control. None of the vitrification projects is a closed system - each of them are expected to require modification of items and procedures as experience is gained during testing and operations. The final step in the methodology is to establish a modification control system which ensures that the consequences of any modification for waste form acceptance are examined. The DWPE is farthest along in this area. A system is in place which ensures that changes to procedures or items are reviewed for their effects on WAPS compliance. WVDP is modifying their current change control system to achieve the same objective. HWVP will do the same once they move from the design stage into construction and qualification testing.

\section{COMPARISON AND PATH FORKARD}

As described in the previous section, there is a general consistency of approach among the three waste form producers to identifying items and activities important to waste acceptance. Each is using the same types of information as the basis for making the identification. Each is using an analysis of the consequences of failure of individual items and activities to make the determination. Prior to production, each producer will have systems in place to ensure that modifications to items or activities are examined in terms of their implications for compliance with the WAPS.

However, there are some differences among the producers which warrant further interactions.

- The WVDP approach provides a documented decision of each item or activity considered. Although the west valley approach is equivalent to the DWPF approach, its output (the HLW screening forms) is more "auditor-friendly." Adaptation of this by the DWPF could eliminate some of the special documentation which the DWPF has been required to produce to justify not applying RW0214 to itams which are not important to waste form acceptance.

- The DWPF has a system in place, and working, to ensure modifications are appropriately screened, and their effects on waste form acceptance considered. This system, and the lessons learned from its implemertation, can be usefully applied by the other producers.

- The HWVP is using a design basis approach which provides the bases for controlling any future design modifications which are needed. Such a system may also be useful to the other 
producers.

- The use of the list of items and activities to facilitate a graded approach to the application of quality assurance requirements needs to be closely examined. Given the time and costs associated with the government procurement process, for example, there could be significant savings realized by utilizing a more closely integrated approach among the three producers.

\section{REFFRENCES}

1. Office of Environmental Restoration and Waste Management, Waste Acceptance Product Specifications for Vitrified High-Level Waste Forms, Revision 0, USDOE Document EM-WAPS, U.S. Department of Energy, Germantown, MD (1993). 
APPROVED BY GOCO HIM VTRRIFICATION COMMITTEF

Ewithel pahenter

Defense Waste Processing Facility

Hanford Waste Vitrification Plant

West Valley Demonstration Project 


\section{ATTACHMENT 1}

\section{DWPF METHODOLOGY FOR IDENTIFICATION OF WASTE ACCEPTANCE ITEMS/ACTIVITIES}

\section{Introduction}

The Waste Acceptance Product Specifications (WAPS) outline the requirements that the DWPF product must meet in order to be acceptable to the repository program. The Quality Assurance Requirements Document, RW-0214 must be applied in a graded manner to those items and activities that have been determined to be important to the waste acceptance process (i.e. necessary for compliance with the WAPS). In order to select the items and activities that are important to the waste acceptance process (i.e. define the scope of the quality assurance program) the DWPF has used the following as the primary selection criterion:

The item/activity must be an essential part of compliance with the WAPS based on the strategies outlined in the DWPF Waste Form Compliance Plan (WCP).

The DWPF WCP describes in detail how the DWPF will produce a product which complies with the WAPS, thus, the strategies in the WCP must be used as a basis for this evaluation. If the failure of an item or activity could result in a nonconforming canistered waste form or if the item/activity generates data for the Production Records it was considered to be important to the waste acceptance process.

Items/activities dealing with a Shipping Facility have not yet been considered by the DWPF because a design for such a facility does not yet exist, and will not for several years. However, the same criterion must apply for the Shipping Facility, i.e. the item/activity must be an essential part of compliance with the WAPS based on the strategies in the WCP.

\section{Evaluation of the DWPF Process}

In order to develop the envelope of items and activities within the DWPF process which are important to compliance with the WAPS, the DWPF process was evaluated system by system. A system was defined by a major piece of processing equipment (e.g. melter) or by major processing actions (e.g. glass pouring). Thus, by evaluating all equipment and processing systems the entire process was examined.

The first step in the evaluation process was to determine the major attributes of each system and associate them with a particular specification(s) (WAPS) using the WCP compliance strategies as a basis. Equipment, activities (e.g. inspections, data collection), and personnel were considered as major attributes for each system. The systems and their attributes were then broken down further into items/activities and evaluated using the primary selection criterion that the item/activity must be an essential part of compliance with the WAPS based on the stratc gies outlined in the DWPF Waste Form Compliance Plan (WCP). To assist in the evaluation process the following questions were also used:

- Could the failure of the item/activity result in a nonconforming canistered waste form?

- Does the item/activity generate data for the Production Records?

DWPF standard operating procedures have also been evaluated as a separate exercise so that any steps that affect the waste acceptance process can be flagged in the procedure. 
A description of the DWPF evaluation process along with the current listing of items/activities is maintained in the DWPF Waste Acceptance Reference Manual, WSRC-IM-93-45.

\section{Control of Items/Activities}

Most of the DWPF equipment selected as important to the waste acceptance process was purchased and installed prior to implementation of the current quality assurance program. However, any design changes of existing equipment or future procurements will be controlled under the current quality assurance program. Design changes are controlled through the design change control process using the following implementing procedures:

- SOP-QI-603-0, Design Change Control Program

- SOP-QI-603-15, DWPF Design Change Con' 1 for Project S1780/S4342

- SOP-CT-10.02, Technical Review Procedure

The DWPF cognizant engineer performs the first review of the design change request during the technical screening process. The cognizant engineer determines if the change is waste acceptance impacting using the items and activities identified in the DWPF Waste Acceptance Reference Manual as a basis. If the item is determined to be waste acceptance impacting, the DWPF Waste Acceptance Group's (WAG) signature is required as part of the technical screening. This signature indicates that they are aware of the proposed change and will evaluate whether it will affect the DWPF's ability to comply with the WAPS or if it will require a change to the waste acceptance documentation. The WAG will involve the Savannah River Technology Center (SRTC) in the evaluation process, as appropriate.

After the design is completed it is returned to the cognizant engineer for a technical review (SOPCT-10.02). If the design change had been previously determined to be waste acceptance impacting, WAG approval is required before the change can be implemented. WAG approval indicates that the WAG concurs with the change and that it will have no effect on the ability of the DWPF product to comply with the WAPS. If any additional was necessary the WAG will ensure that the necessary tests or studies are completed before the change is implemented. This may require input and assistance from SRTC.

When reviewing design changes the Waste Acceptance Group follows the steps listed below:

1) Using the compliance strategies in the WCP as a basis, determine if the change impacts the ability of the DWPF to comply with the WAPS or if the change affects the existing method of compliance.

2) Determine if the design change invalidates any startup testing to date that provides input to the Waste Form Qualification Report.

3 ) If the ability to comply or the method of compliance is affected (step 1), determine if further testing is necessary to demonstrate the DWPF's ability to comply or if any other item requires a change (e.g. removal of a procedure step may require a new procedure).

4) If startup testing is impacted (step 2), recommend what additional testing needs to be performed.

5) If the ability to comply or the method of compliance is affected (step 1) determine if any changes need to be made to waste acceptance documentation.

6) Ensure testing has been completed, if necessary, prior to the implementation of the design change.

7) Revise waste acceptance documentation, if necessary, and send through the review process. 
Modifications to standard operating procedures that contain waste acceptance impacting activities must also be approved by the Waste Acceptance Group.

If a procurement is necessary, DWPF Quality Assurance, with the assistance of DWPF Technical \& Engineering (including the Waste Acceptance Group), will include the appropriate quality assurance controls in those procurement specifications for items important to waste acceptance. 
WHC-SD-HWV-RD-005

Revision 0

Figure 2-1. Logic Diagram for Application of DOE/RH-0214.

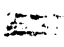

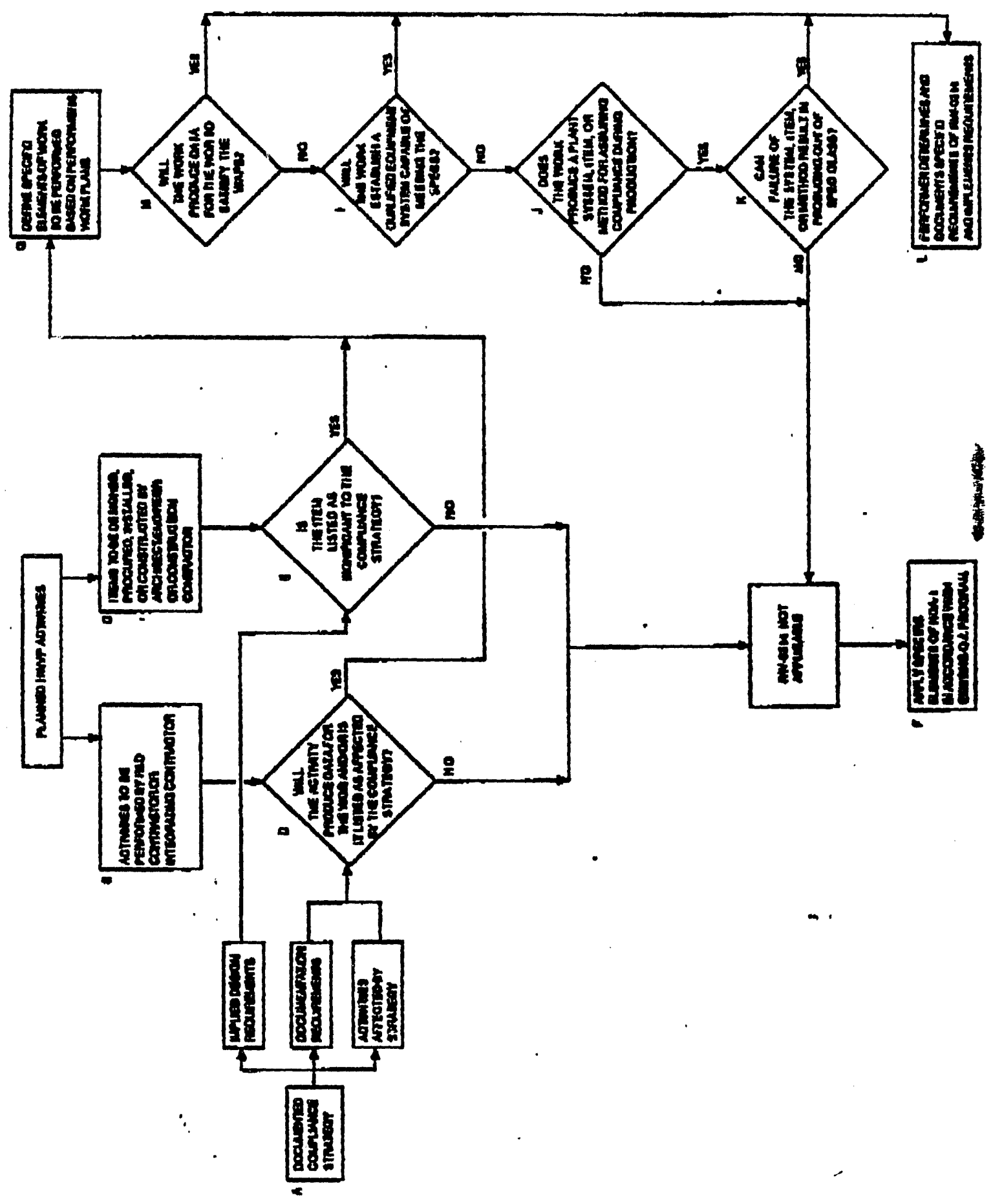




\section{ATTACHMENT 2}

\section{HWVP METHODOLOGY TO IDENTIFY WASTE ACCEPTANCE PROCESS ACTIVITIES}

\section{SUBJECT}

This document describes how the HWVP Project implemented and integrated the DOE Waste Acceptance Process (WAP) (DOE 1985; and the DOE quality assurance (RW-0214, 1990) requirements relative to:

a) identifying activities that produce data and information needed for preparing the waste form (product) qualification (WFQ) documentation per the DOE-WAP and

b) when RW-0214 became available, aeriving a waste acceptance process activities (WAPA) identification methodology and implementing its application into the WFQ work of project participants such as the research and development contractor (Pacific Northwest Laboratories/PNL) and the HWVP designer (Fluor Daniel/FD).

\section{GENERAL BACKGROUND SUMMARY}

Initially, the HWVP Project decided by an expert judgment/consensus process which activities were needed to produce data and information for preparing the WFQ documentation called out by the DOE-WAP (1985). This WFQ identification was built into the Project's baseline planning description and into the respective statements of work (SOWs) for each project participant (e.g., PNL, FD, etc.). For the HWVP design, the DOE (RW) Waste Acceptance Preliminary Specifications (WAPS) were used, along with draft compliance strategy thinking relative to the design activity, to create WFQ compliance guidance information relative to each specification in the RW-WAPS. This guidance for the design was put in Section 18 of the Technical Data Package (TDP) for the Project.

Subsequently, the Project completed, in the listed order, the following supporting documentation relative to WFQ planning and implementation by the Project: a selection methodology and procedure for identifying which activities were Waste Acceptance Process Activities (WAPA), per RW-0214; and under the mantle of WFQ activities, the "HWVP WFQ Compliance Strategy and Implied Design Requirements" report, a draft for project review of the "HWVP Waste Compliance Plan" (i.e., WCP) and, recently, the "HWVP Waste Form Qualification (WFQ) Program Plan" report.

The HWVP designer (FD), in further implementing RW-0214, utilized the preceding guidance and prepared the following documentation:

a) a WAPA rationale document,

b) WAPA design procedures and

c) a series of WAPA analysis reports (i.e., relative to hardware components initially judged to be potentially integral with the WAPA methodology selected activities).

The WAPA analysis reports are being used to refine the initial listing of the WAPA items and to support preparation of the HWVP component procurement packages.

Related Project activities to be completed include the development of

a) the HWVP systems acceptance requirements, 
b) the HWVP system description documents,

c) the planning for HWVP qualification testing and

d) implementing procedures for waste acceptance.

As it has been since the inception of the HWVP Project as a Major System Acquisition (MSA), the top-level guiding strategy for the Project is to...use to the maximum extent practical the technology (i.e., designs, methods, testing results, approaches, etc.) from the other two US high-level waste vitrification projects. This strategy focuses especially upon the Defense Waste Processing Facility (DWPF) Project at the DOE Savannah River Site.

\section{HWVP WFQ AND WAPA SELECTION METHODOLOGY AND APPLICATION}

\section{General Implementation}

The selection methodology for identifying activities needed per DOE/RW-0214 (WAPA) and WFQ documentation is illustrated in the attached figure.

An activity may be identified as producing data to be included in the documentation required by the compliance strategy and/or listed as an activity affected by the compliance strategy. These activities were assessed based upon specific elements of work to be performed. If the work affects a plant system, item, or method for ensuring compliance, it is then evaluated relative to WAPA and the single point failure criteria that the HWVP Project adopted. It would be excluded if it can be shown that a failure will not result in producing an out-of-compliance waste form product.

As the compliance strategy continues to develop and evolve, the Project has determined (and updated) and dscumented listings of the activities (i.e., WAPAs) needed to help establish the respective compliance basis. This WAPA activities listing has been done in relation to the work of each of the HWVP Project Participants. The documentation defining and controlling the respective work of each of these Participants contains identification as to which activities come under the mantle of WFQ/RW-0214 control by the Project.

The specific approach that the HWVP Project has chosen for implementing WFQ compliance basis planning, and, more specifically, the associated WFQ QA implementation planning of RW-0214, has been to focus on what needs to be defined and implemented with respect to the particular "phase or part" of the HWVP Project that was underway at that time. This has essentiplly been the general approach of each of the three US HLW vitrification projects, since each of these projects was already underway before most of the WFQ/RW-0214 requirements were imposed. Thus the particular focus for the HWVP Project has been on the HWVP design and the research and development testing. In the case of the design, the Project has chosen a general approach to developing the WAPA activities list, and especially the associated items listing, that started with a very conservative (i.e., broad) listing. Then, through additional review, and especially the usage of the WAPA analysis reports, the listing has been refined and typically reduced in size. HWVP Project reviews of WAPA analysis have benefitted from periodic participation of DWPF and WVDP staff and comparisons to their activities selection rationale.

\section{Design Implementation of WAPA}

Based upon the above developments, Fluor Daniel (the Project AE) derived a conservative and comprehensive listing of design components related to the then apparent compliance bases for meeting the WAPS.

A WAPA Rationale Report was prepared to present the rationale for designating equipment, controls, and piping etc. important to WAPA, and to present the type of qualifications that could be 
required for the designated system components. Items were identified as WAPA if an undetected failure of the element could cause a canistered waste form to be off-specifications; or if the element could cause an unrecoverable loss of data necessary to WFQ due to its failure even if the failure is detected; or if a faulty element is detected, it cannot be repaired or replaced in time to prevent an inevitable and disqualifying change in the waste form from happening. This screening significantly reduced the size of the listing of affected design components.

In these selections a graded QA was applied. These identified items are considered preliminary. As the design process proceeds, these items are documented in a final WAPA Report for each applicable procurement/construction package. The analysis included in this report flags items for consideration during testing, startup, qualification, and operation.

Design acceptance methods as defined in the procurement packages are currently being reviewed for applicability to the preparation of the WCP/WQR. 
WHC-SD-HWV-RD-005

Revision 0

Figure 2-1. Logic Diagram for Application of DOE/RW-0214.

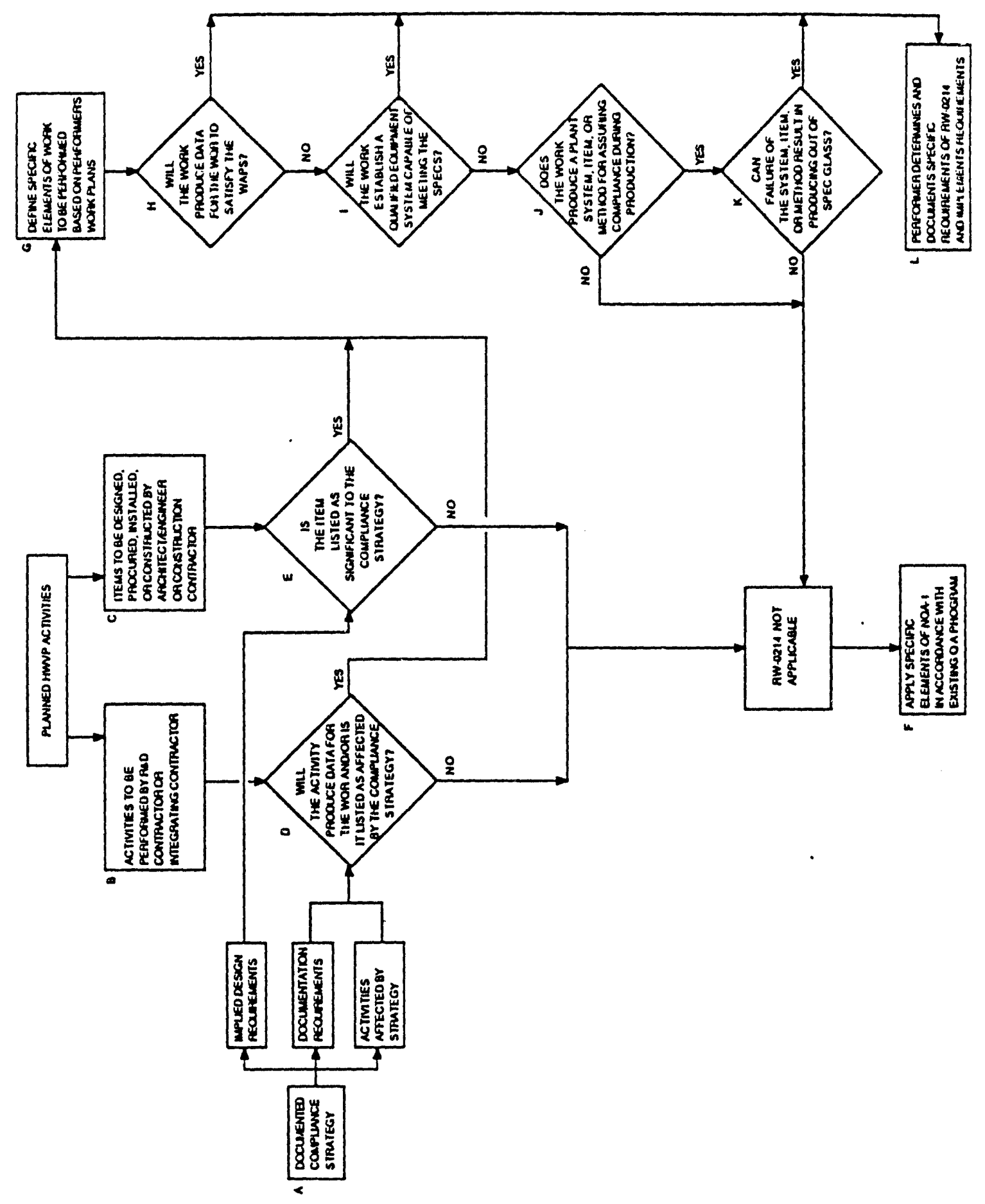




\section{ATTACHMENT 3}

\section{METHODOLOGY FOR DETERMINATION OF RW-0214 APPLICABILITY AT WVDP}

\section{INTRODUCTION}

In order for RW-0214, OCRWM Quality Assurance Requirements Document to be implemented at WVDP in a consistent and certifiable manner, it is necessary to define the "envelope" of applicability. It is recognized that this definition must clearly delimit current items and activities for which the amplified Quality Assurance requirements of RW-214 are applicable. It must also be structured so that it can evolve to encompass new activities as they become part of the Waste Acceptance Process scope. The following is the methodology that has been adopted to accomplish this purpose.

\section{PREPARATION OF BASELINE HLW ITEMS AND ACTIVITIES LIST:}

\section{Determine Criteria for RW-0214 Applicability}

The following questions were used to determine whether the enhanced requirements of RW-0214 were applicable to an item or activity:

1. If the activity is not performed or is performed incorrectly, could the result be an out-ofspec canistered waste form (CWF)?

2A. Is information provided by the activity required for performance of a subsequent activity?

2B. If yes, could inaccurate information result in an out-of-spec CWF?

3. Could undetected failure of the item to perform its design function result in an out-of-spec CWF?

4. Could detected failure of the item result in an out-of-spec CWF due to the impossibility of required repairs in a necessary time frame?

\section{Construct Process Flowsheet}

A flowchart was constructed identifying the activities that are required for the WVDP canistered waste form production process. The scope of the flowchart was from development of the glass recipe and design of the canister through shipout of the CWF.

\section{Apply Criteria to Activities on the Flowchart}

The criteria described above were applied to each activity appearing on the process flowchart. The decision as to whether RW-0214 requirements were applicable was recorded, with a rationale for the decision, on HLW Screening Forms for each activity. This was done in accordance with a WVNS Engineering Procedure. All of the activities screened were then recorded, with the appropriate RW-0214 applicability indicator (yes or no), on a baseline WVDP HLW Items and Activities List.

\section{MAINTENANCE OF HLW ITEMS AND ACTIVITIES LIST}


The WVDP HLW Items and Activities List is controlled, distributed, and updated per an Engineering Procedure, EP-2-001, Determination of Required HLW Designation. This procedure is implemented per instructions currently being incorporated into procedures governing the initiation of activities and the procurement of items. 


\section{APPROYED AY GOCO BIH VITRIEICATION COYKITTER}

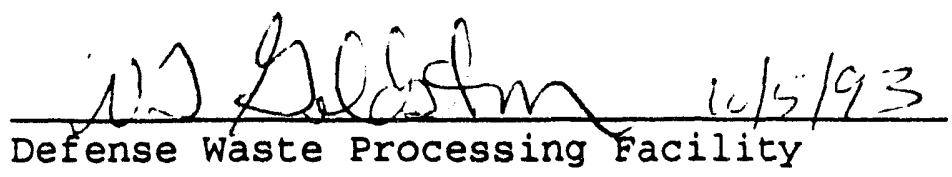

Hanford Waste Vitrification Plant

West Valley Demonstration Project 
APPROYBD BY GOCO BIII YITRIEICATION COMMTTMER

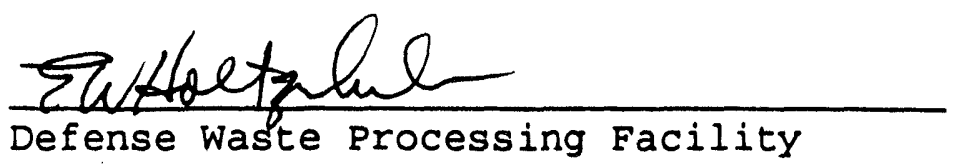

Hanford Waste Vitrification Plant

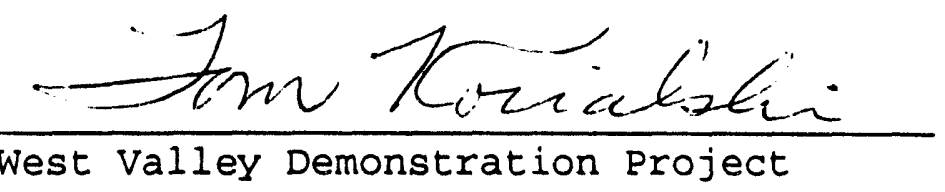


APPROVED BY COCO BIT VITRIFICATION COMMITTER

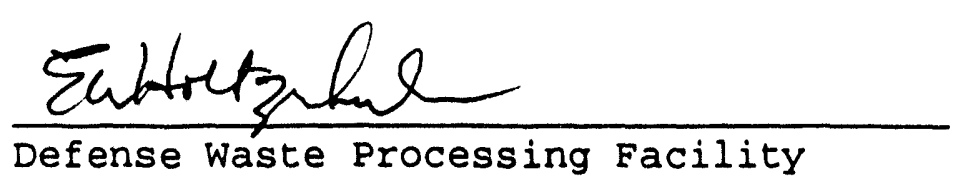

¿ Muller

Hanford Waste Vitrification Plant

West Valley Demonstration Project 

